Int. J. Dev. Biol. 57: 309-317 (2013)

doi: $10.1387 / \mathrm{ijdb} .130142 \mathrm{ka}$

\title{
Epigenetic features of testicular germ cell tumours in relation to epigenetic characteristics of foetal germ cells
}

\author{
DINA G. KRISTENSEN, NIELS E. SKAKKEBAEK, EWA RAJPERT-DE MEYTS and KRISTIAN ALMSTRUP* \\ Department of Growth and Reproduction, Copenhagen University Hospital, Rigshospitalet, Copenhagen, Denmark.
}

\begin{abstract}
Foetal development of germ cells is a unique biological process orchestrated by cellular specification, migration and niche development in concert with extensive epigenetic and transcriptional programs. Many of these processes take place early in foetal life and are hence very difficult to study in humans. However, the common precursor of testicular cancers - the carcinoma in situ (CIS) cell - is thought to be an arrested foetal germ cell. Therefore studies of CIS cells may leverage information on human foetal germ cell development and, in particular, when neoplastic transformation is initiated. In this review, we will focus on current knowledge of the epigenetics of $\mathrm{CIS}$ cells and relate it to the epigenetic changes occurring in early developing germ cells of mice during specification, migration and colonization. We will focus on DNA methylation and some of the best studied histone modifications like H3K9me2, H3K27me3 and H3K9ac. We also show that CIS cells contain high levels of H3K27ac, which is known to mark active enhancers. Proper epigenetic reprogramming seems to be a pre-requisite of normal foetal germ cell development and we propose that alterations in these programs may be a pathogenic event in the initiation of testicular germ cell cancer. Even though only sparse information is available on epigenetic cues in human foetal germ cells, these indicate that the developmental patterns differ from the findings in mice and emphasize the need for further studies of foetal germ cell development in humans.
\end{abstract}

KEY WORDS: primordial germ cell, gonocyte, epigenetics, carcinoma in situ testis

\section{Introduction}

The natural history of germ cells is characterised by several developmental milestones which are characterised by early embryonic pluripotency, followed by gradual increase in germ-cell specific factors and a post-pubertal onset of meiotic division required to produce haploid gametes. During early foetal development, migrating primordial germ cells (PGCs) as well as gonocytes undergo extensive epigenetic modifications, which include erasure and re-establishment of DNA methylation and exchange of histone modifications. These sequential changes in epigenetic modifications, occurring within a narrow developmental time window, is termed epigenetic reprogramming and seems to be a prerequisite of normal germ cell development. It is well recognized that epigenetic modifications are susceptible to alterations when exposed to environmental factors (Reviewed in Feil and Fraga, 2011). Indeed, animal studies show that certain exposures during foetal development cause epigenetic alterations with a phenotypic outcome, including alterations in the development of male germ cells.
There is growing evidence that testicular germ cell-derived tumours (TGCTs) in humans profoundly differ in their gene expression profiles and epigenetic regulation from normal germ cells residing in the adult testis. Epigenetic reprogramming of TGCTs is sensitive to environmental exposures, hence etiological factors seem to be linked to environmental cues. This pinpoints that the epigenetic layer of information in foetal germ cells is detrimental in the pathogenesis of testicular cancer (TC). In this article we shall review the current knowledge on the epigenetics of TC, with focus on the precursor lesion, carcinoma in situ (CIS) and relate these findings to the epigenetic changes occurring in early developing germ cells.

Abbreviations used in this paper: CIS, carcinoma in situ; PGCs, primordial germ cells; TGCTs, testicular germ cell-derived tumours; TC, testicular cancer; TDS, Testicular Dysgenesis Syndrome; ITGCN, intratubular germ cell neoplasia unclassified; TIN, testicular intraepithelial neoplasia; GW, gestational week; $5 \mathrm{mC}$, DNA methylation at the $5^{\text {th }}$ position of cytosine; $5 \mathrm{hmC}$, hydroxymethylation at the $5^{\text {th }}$ position of cytosine; EC, embryonal carcinoma; TSGs, tumour suppressor genes; $\mathrm{SS}$, spermatocytic seminoma.

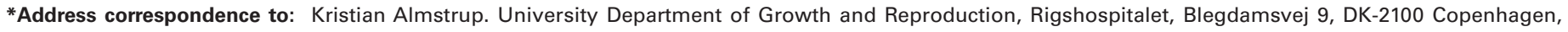
Denmark. Tel: (+45)-3545-6639/4330. Fax: (+45)-35456054. e-mail: kristian@almstrup.net
} 


\section{Testicular cancer: epidemiology and pathology}

In most western countries TGCTs are the most frequent malignancy found among young males. In Norway and Denmark they account for approximately $1 \%$ of all cancers in men. Worldwide, TC has more than doubled in the last 40 years, but the incidence varies considerably in different geographical areas and also between ethnic groups (Huyghe et al., 2003). TGCTs is 4.5 times more common among white men than black men in the USA (Moul et al., 1994) and twice more frequent in Denmark than Sweden (Chia etal., 2010). Interestingly, analysis of incidence rates among immigrants to Sweden (including men from Chile and Finland) has revealed that the first-generation immigrants have similar rates to the men in their country of origin, whereas the second-generation men acquire the Swedish risk irrespectively of the parental geographical origin, indicating that the place of birth determines the risk of TC and implying that in utero environmental exposures play a large role as risk factor (Hemminki and Li, 2002a, Hemminki and Li, 2002b, Hemminki et al., 2002). Recently Norway and Denmark were reported to have the highest and second highest incidence of TC in the world (Chia et al., 2010). Chile was reported to have the third highest incidence, which indicates that high TC incidence is not confined to the closely related environment found in Nordic European countries.

Clinical risk factors for TC include male infertility $(R R=3)$ (Mancini et al., 2007, Walsh et al., 2009) and a history of cryptorchidism $(\mathrm{RR}=2-8)$ (Dieckmann and Pichlmeier, 2004, Wood and Elder, 2009). Some cases of cryptorchidism, male infertility, and most TGCTs share the common feature of foetal developmental origins. Furthermore, histological investigations showed that TGCTs often coincides with dysgenetic tubules presenting spermatogenic arrest, microcalcifications, poorly differentiated Sertoli cells, Sertoli-cellonly pattern etc. (Hoei-Hansen et al., 2003). These observations, among others, linked TGCTs to other disorders of male reproduction, and led to the proposed grouping of these disorders within the so-called Testicular Dysgenesis Syndrome (TDS) (Skakkebaek et al., 2001). Growing evidence suggests that the majority of cases of TDS are caused predominantly by external factors, which may act directly on numerous pathways involved in testis development. The factors remain to be identified and proven causative, but factors related to modern lifestyle, including endocrine disruptors have been under growing scrutiny as possible culprits. Indeed, evidence from animal models indicates that perinatally administered endocrine disrupters, like phthalates, can induce dysgenic lesions in the testes of rats and rabbits (Fisher et al., 2003, Foster et al., 2001, Higuchi et al., 2003), similar to those frequently observed in patients with TGCTs (Hoei-Hansen et al., 2003, Skakkebaek et al., 2003). Interestingly, primarily somatic cells, in particular Leydig cells, and not directly germ cells, seem to be affected (Mahood et al., 2005). The effect on germ cells thus seems to be secondary but nevertheless adversely affecting their perinatal development. Increased and widespread use of industrial products which act like endocrine disrupters (e.g. phthalates) combined with an increase in endocrine-related diseases, which may cause dysgenesis of the testis (e.g. obesity), have thus raised growing concerns of possible association between exposure of endocrine disrupting chemicals and human adverse effects. Indeed, elevated levels of chemicals, such as polychlorinated biphenyls, hexachlorobenzene and chlordanes have been detected in blood from the mothers of men with TC (Hardell et al., 2003). The dramatic increase in TC observed over few generations suggests that the effect on the cellular level should be either a direct (affecting transcription factors directly) or an epigenetic effect inflicting foetal germ cell differentiation.

The vast majority of TGCT occur in young men and manifest either as a seminoma or non-seminoma. These are different both in terms of histology and treatment regimes but appear equally frequent. Seminoma is a homogeneous tumour composed of mitotically dividing germ cells, whereas non-seminomas are heterogeneous tumours that may contain varying proportions of undifferentiated embryonal carcinoma, partially differentiated somatic tissues (teratoma), and extra-embryonic elements such as choriocarcinoma and yolk sac tumour (Ulbright et al., 1999). Both of these tumour types are preceded by a symptom-less pre-invasive stage, the carcinoma in situ (CIS) cell (Skakkebaek, 1972) also known as intratubular germ cell neoplasia unclassified (ITGCN) or testicular intraepithelial neoplasia (TIN). CIS cells are often found in usually normally arranged seminiferous tubules where these cells are situated along the peritubular membrane, as shown in Fig. $1 \mathrm{~A}$.

According to our hypothesis, under-stimulation or dysregulation of primordial germ cells (PGCs) or gonocytes during early development is a key event leading to an arrest in germ cell differentiation and hence formation of "dormant" CIS cells, that later in life progress to invasiveness and TGCTs. In similarity to embryonic stem cells and early foetal germ cells, CIS cells retain a high expression of pluripotency genes (Almstrup et al., 2004) and virtually no difference was found between gene expression profiles of microdissected gonocytes and CIS cells (Sonne et al., $2009 b)$. These observations substantiate our hypothesis that the formation of CIS cells is a result of impaired differentiation and developmental arrest of foetal germ cells. We further hypothesize that the developmental arrest is caused by disruption of the endocrine environment of the testis niche. The niche is comprised of somatic cells; mainly Sertoli- and Leydig cells as well as peritubular cells, which secrete hormones and paracrine factors that stimulate male-specific germ cell maturation into spermatogonia (Rajpert-De Meyts, 2006). The stimulation of "dormant" CIS cells in the pubertal testis is thought to increase proliferation and accumulation of genomic changes, which at some point trigger a malignant phenotype.

\section{Epigenetic cues in developing foetal germ cells}

In order to understand the epigenetic disruptions on germ cells leading to development of CIS it is a prerequisite to understand the reprogramming of normal foetal germ cells. Most of our current knowledge on foetal germ cell development comes from studies in mice, probably due to difficulties in obtaining sufficient material for human studies. The subsequent sections will hence focus on epigenetic cues in foetal mouse germ cells followed by a section summarizing the sparse knowledge of epigenetics in human germ cell development.

\section{Specification}

During embryonic development, PGCs are specified from a subset of posterior proximal epiblast cells which are first observed at embryonic day E7.25 (mice) in the posterior end of the primitive 
streak. Blimp1 positive cells are however already seen at E6.25 and mark founder PGCs, which prior to E6.25 are indistinguishable from somatic neighbours (Ohinata et al., 2005). Blimp1 is crucial for normal germ cell specification and is thought to be engaged in suppression of somatic programs by Hox genes (i.e. HoxA1 and HoxB1) (Ohinata et al., 2005), which already have been initiated at E6.25. In the few founder (approximately 40 PGCs) and migrating PGCs Blimp1 is found in the nucleus in complex with Prmt5, where it mediates symmetrical di-methylation of histones $\mathrm{H} 4$ and $\mathrm{H} 2 \mathrm{~A}$ at arginine 3 (H4/H2AR3me2). When murine PGCs arrive in the genital ridge, the complex translocates to the cytoplasm, leading to reduced levels of $\mathrm{H} 4 / \mathrm{H} 2 \mathrm{AR} 3 \mathrm{me} 2$ (Ancelin et al., 2006). Translocation of Blimp1/Prmt5 to the cytoplasm leads to downregulation of Blimp1, which in turn coincides with re-expression of pluripotency-associated genes, including Nanog and Sox2
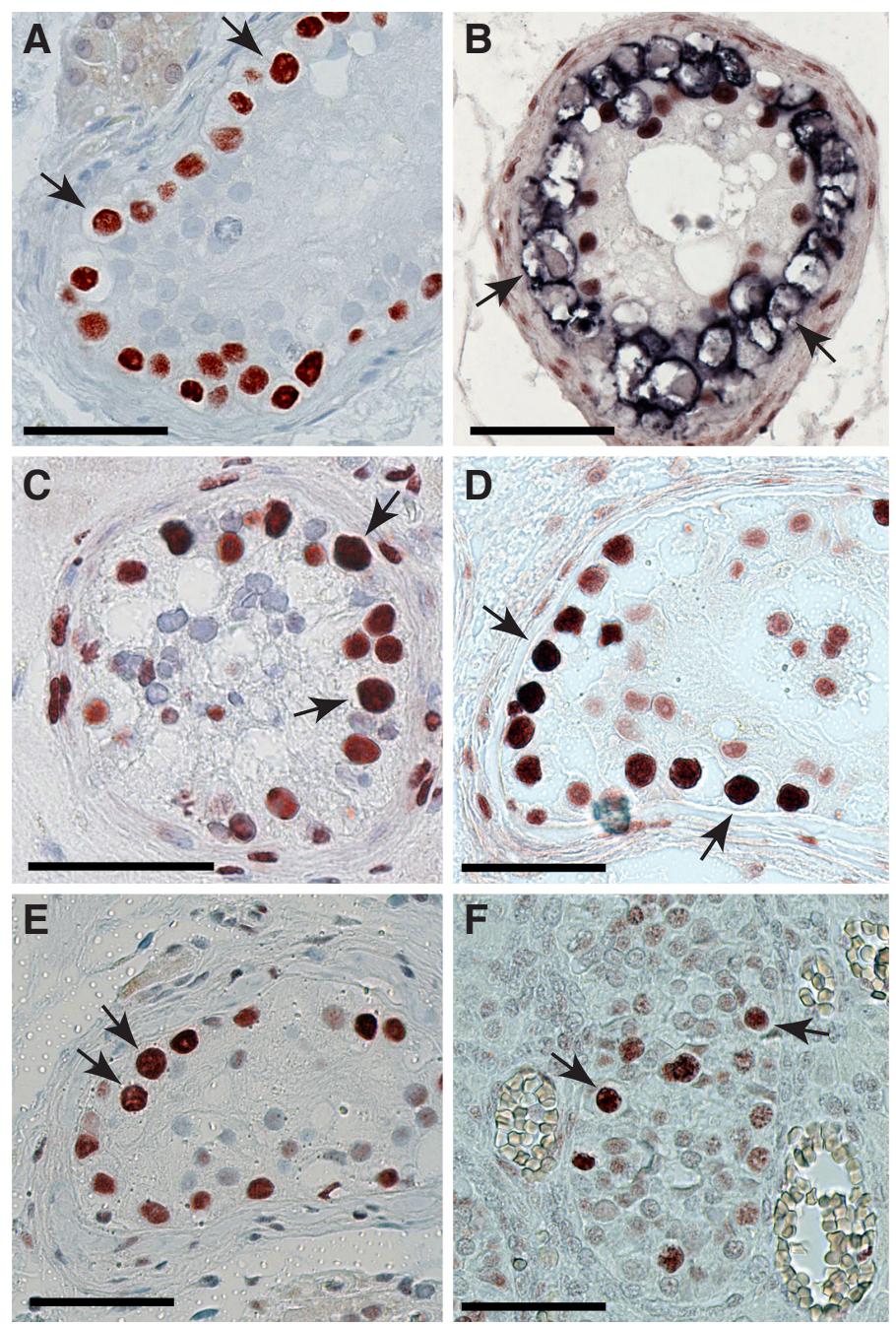

Fig. 1. Examples of immunohistochemical stainings of tissue containing carcinoma in situ (CIS) cells or gonocytes. (A) CIS cells (arrows) express the transcription factor AP-2 $\gamma$ gamma (TFAP2C; Hoei-Hansen et al., 2004). (B) Double staining with PLAP, a classical CIS marker, in blue and 5-methylcytosine in red. CIS cells (arrows) show no staining with 5-methylcytosine, whereas somatic Sertoli cells stain intensively. CIS cells (arrows) display the following histone modifications: (C) H3K27ac, (D) H3K4me1 and (E) H3K9ac. (E) Gestational week 21 gonocytes (arrows), which like CIS cells, display staining for H3K9ac. All bars represent 50 microns.
(Ohinata et al., 2005, Yabuta et al., 2006). In this particular stage, there is a significant difference between species: human PGCs do not express SOX2 but retain high expression of NANOG and POU5F1 (Perrett et al., 2008).

\section{Migration}

Approximately at embryonic day E8 (mice) PGCs start to migrate towards the genital ridge and colonize the primitive gonad, which is tightly associated with the mesonephros. The primitive gonad is still sexually bipotential and sex-determination first takes place between E10.5 and E11.5.

During specification and migration PGCs undergo epigenetic reprogramming, including genome-wide DNAde-methylation (starting at E8), progressive erasure of $\mathrm{H} 3 \mathrm{~K} 9 \mathrm{me} 2$ (starting at E7.5) and subsequently establishment of H3K27me3 (starting at E8.25) in a progressive, cell-by-cell manner, presumably depending on their developmental maturation (Seki et al., 2005, Seki et al., 2007). DNA methylation and the above-mentioned histone modifications are repressive epigenetic marks associated with DNA silencing. The loose chromatin structure would allow massive transcription, but in this period transcription in PGCs is kept silent by transient repression of RNA polymerase II-dependent transcription (Seki et al., 2007). In addition, prior to H3K9 de-methylation PGCs repress the histone methyltransferase, GLP, which mediates H3K9 methylation (Tachibana et al., 2008).

The genome-wide DNA de-methylation is suggested to occur due to the downregulation of the DNA methyltransferase Dnmt1, which maintains methylation patterns of mother strands after DNA replication. Dnmt1 is transiently downregulated at least in a portion of PGCs after the time of their fate determination, and is subsequently re-expressed by the time of their migration (E8.25) (Seki et al., 2005).

In humans, migration of PGCs takes place during gestational week (GW) 4-6 and after GW 6 germ cells are found in the gonadal region and immature Sertoli cells begin to surround them. From that point of time, the term gonocyte is used to describe the germ cells in the male gonad (Fujimoto et al., 1977).

\section{Colonization}

Arrival in the genital ridge seems to set a critical milestone in the germ cells development, because at this stage a cascade of epigenetic events takes place, leading to differentiation of the surrounding niche into male or female characteristics. In murine PGCs the colonization of the genital ridge (E11.5) is associated with extensive chromatin and epigenetic reprogramming involving linker histone $\mathrm{H} 1$, H3K9ac, H3K9me2, H3K27me3, DAPI chromocenters and H4/H2A R3me2 (Hajkova et al., 2008) and a second wave of DNA de-methylation (the first wave occurs during pre-implantation), where parental imprints are erased (Hajkova et al., 2002). Some parental imprints are already set again starting at E14.5, while others are first acquired at the new-born stage (Li et al., 2004). By FACS analysis of dissected urogenital ridges of an Oct4-GFP transgenic mouse, Hajkova et al., (2008) identified two Oct4+ (GFP) populations of PGCs at E11.5. These two populations were shown to reflect a developmentally primitive and a more advanced PGC population. The advanced population showed low levels of H2A.Z, linker H1, H3K9ac, H3K9me2 and H3K27me3 as well as H2A/H4R3me2, when compared to the primitive population showing higher levels of these marks. Accordingly, 
the primitive population showed variations in the levels of DNA methylation (5-methyl-cytosine levels), whereas the advanced population was practically devoid of DNA methylation (Hajkova et al., 2008). A rapid erasure of DNA methylation has been found to occur between E10.5 to E12.5 at imprinting control regions (ICRs) in murine PGCs colonized in the gonadal ridge (Hajkova et al., 2002). However, a recent study investigated the methylation status of gene promoters in PGCs by MeDIP-sequencing, and showed that de-methylation was already initiated during migration at E9.5, with a complete erasure of DNA methylation occurring between E11.5 and E12.5 (Guibert et al., 2012). This indicates that different kinetics of de-methylation exist, as non-imprinted regions are de-methylated with an earlier onset compared to de-methylation of ICRs. In line with these observations Popp et al., (Popp et al., 2010) found that only 15\% of the mouse PGC genome at E13.5 was methylated. Interestingly, in mice with knock-out of the DNA deaminase (Aid) a significant increase in PGC-methylation was observed indicating implication of AID in the de-methylation of PGCs. Deamination of a methylated C $(5 \mathrm{mC})$ by AID results in conversion of the $C$ into $T$ and hence $a$ $\mathrm{T}-\mathrm{G}$ mismatch, which is recognized and repaired by the baseexcision repair (BER) machinery. In line with these observations, Hajkova et al., (Hajkova et al., 2010) found an upregulation of genes involved in BER, including Parp1, Ape1, and Xrcc1, in PGCs. However, other parallel mechanisms of active DNAde-methylation exist, which among other possibilities, implicate conversion of $5 \mathrm{mC}$ into hydroxymethylated-C $(5 \mathrm{hmC})$. Conversion of $5 \mathrm{mC}$ into $5 \mathrm{hmC}$ is catalysed by the ten-eleven translocation (TET) family of proteins. $5 \mathrm{hmC}$ can subsequently be converted into other derivatives of $5 \mathrm{hmC}$ to end as an unmethylated C. Indeed, Tet1 expression was found at high levels in $11.5 \mathrm{dpc}$ PGCs (Hajkova et al., 2010) and it remains to be deduced whether several lines of DNA de-methylation can efficiently substitute each other in order to achieve complete de-methylation. Complete de-methylation seems to be a pre-requisite of achieving pluripotency as the first events in the reprogramming of somatic cells into induced pluripotent stem cells depend on the action of Parp1 and Tet2 (Doege et al., 2012).

Besides the above-mentioned active DNA de-methylation mechanisms passive DNA de-methylation may also occur. This could be facilitated by inhibition of DNA methyl-transferases (both de novo enzymes DNMT3A and B and maintenance enzyme DNMT1). Indeed, PARP1 has been suggested to be implicated in regulation of DNMT1 (Zampieri et al., 2012, Zampieri et al., 2009) together with UHRF1 (Bostick et al., 2007).

Due to extensive epigenetic reprogramming, PGCs that colonize the early gonads attain low levels of DNA methylation and low levels of both active (H2A.Z, H3K9ac) and repressive histone marks (H3K9me2, H3K27me3, H2A/H4R3me2) as well as low expression of linker $\mathrm{H} 1$.

During the colonization of the gonadal ridges, sex-determination of developing germ cells also takes place. Expression of the gene Sry in precursors of Sertoli cells is thought to be one of the most important sex-determination events. If Sry is expressed, this subsequently triggers expression of Sox9 and several other masculinising genes, which are essential for proper Sertoli cell differentiation and formation of cord structures in mice at E12 (reviewed in Koopman, 2010).

\section{Testicular development}

After colonization of the genital ridges, PGCs proliferate and when a sufficient number is reached female germ cells enter meiotic prophase while male germ cells (gonocytes) arrest in the G0/ G1-phase of the cell cycle until after birth. After birth, gonocytes give rise to primitive spermatogonia (spermatogonial stem cells) that start to proliferate and develop into spermatocytes at days 10-14 post natal in mice.

Recently, it was demonstrated in mice that the mitosis-meiosis switch is controlled by Dmrt1 in a sex-specific manner (Krentz et al., 2011, Matson et al., 2010). The sex-dimorphic expression pattern of DMRT1 in human gonads indicates that DMRT1 may play a similar role in regulation of meiotic entry in humans (Jorgensen et al., 2012).

Murine PGCs in the genital ridge are virtually devoid of DNA methylation (Reik and Walter, 2001) but de novo methylation is initiated in male germ cells at E14.5 and thereafter in female germ cells, and mature gametes of both sexes will eventually become highly methylated. Additional DNA de-methylation and histone modifications take place in pubertal and adult male germ cells after meiosis during spermatogenesis (Bernardino et al., 2000, del Mazo et al., 1994, Norris et al., 1994). Histones are exchanged with transition proteins and finally with protamines. It has been suggested that re-methylation and possible further chromatin modifications may occur when spermatozoa undergo final maturation in the epididymis (Xie et al., 2002).

\section{Human germ cell development}

Very little is known about epigenetics in human foetal germ cells; the sparse information indicates that epigenetic cues may be different between human and mouse (Almstrup et al., 2010).

We have shown that human foetal gonocytes in a developing testis around gestational week 24 (GW24), show high levels of the histone variant H2A.Z and histone modifications H3K9ac and H3K4me2/3, but low levels of H3K9me2 and H3K27me3 (Almstrup et al., 2010). In addition, gonocytes at GW19 have been shown to contain H4/H2AR3me2 (Eckert et al., 2008). Even though detailed developmental analysis of histone marks in human germ cells is missing, the above mentioned histone marks of human gonocytes indicates that epigenetic cues between human and mice are different. In mice, H3K27me3 is acquired during migration (Seki et al., 2007) but seems absent in human gonocytes (Almstrup et al., 2010). H3K9ac and H4/H2AR3me2 become less abundant after migration in mice (Hajkova et al., 2008) but seem still present in human gonocytes (Almstrup et al., 2010, Eckert et al., 2008).

Similar to mice, DNA methylation is slowly re-established in foetal gonocytes from GW15 (earliest time point investigated) until around birth where DNA methylation seems similar to their somatic neighbours (Almstrup et al., 2010, Wermann etal., 2010). The re-methylation period in human gonocytes/pre-spermatogonia however seems to be somewhat prolonged compared to what is observed in mice.

Taken together, the sparse information from human foetal germ cells indicates that some differences exist between mice and human epigenetic cues. By contrast, epigenetic patterns of porcine foetal germ cells seem to be similar to those observed in mice (Hyldig et al., 2011a, Hyldig et al., 2011b) and further 
investigation is needed to thoroughly map human epigenetic developmental cues in foetal germ cells.

\section{Epigenetics in the pathogenesis of testicular germ cell cancer}

CIS cells were first described in 1972 by Niels E. Skakkebæk (Skakkebaek, 1972). Probably due to a similar intratubular localization as early spermatogonia, many scientists did not acknowledge this new finding and believed that these cells were abnormal spermatogonia. However, growing evidence indicated that CIS cells indeed were neoplastic cells (Akhtar and Sidiki, 1979, Berthelsen et al., 1979).

Already a few years after the initial discovery of CIS cells morphological studies indicated that the CIS cells were very similar to foetal germ cells (Albrechtsen et al., 1982, Nielsen et al., 1974, Skakkebaek et al., 1987). Later, the immunohistochemical markers for CIS cells; placental-like alkaline phosphatase (PLAP) and the

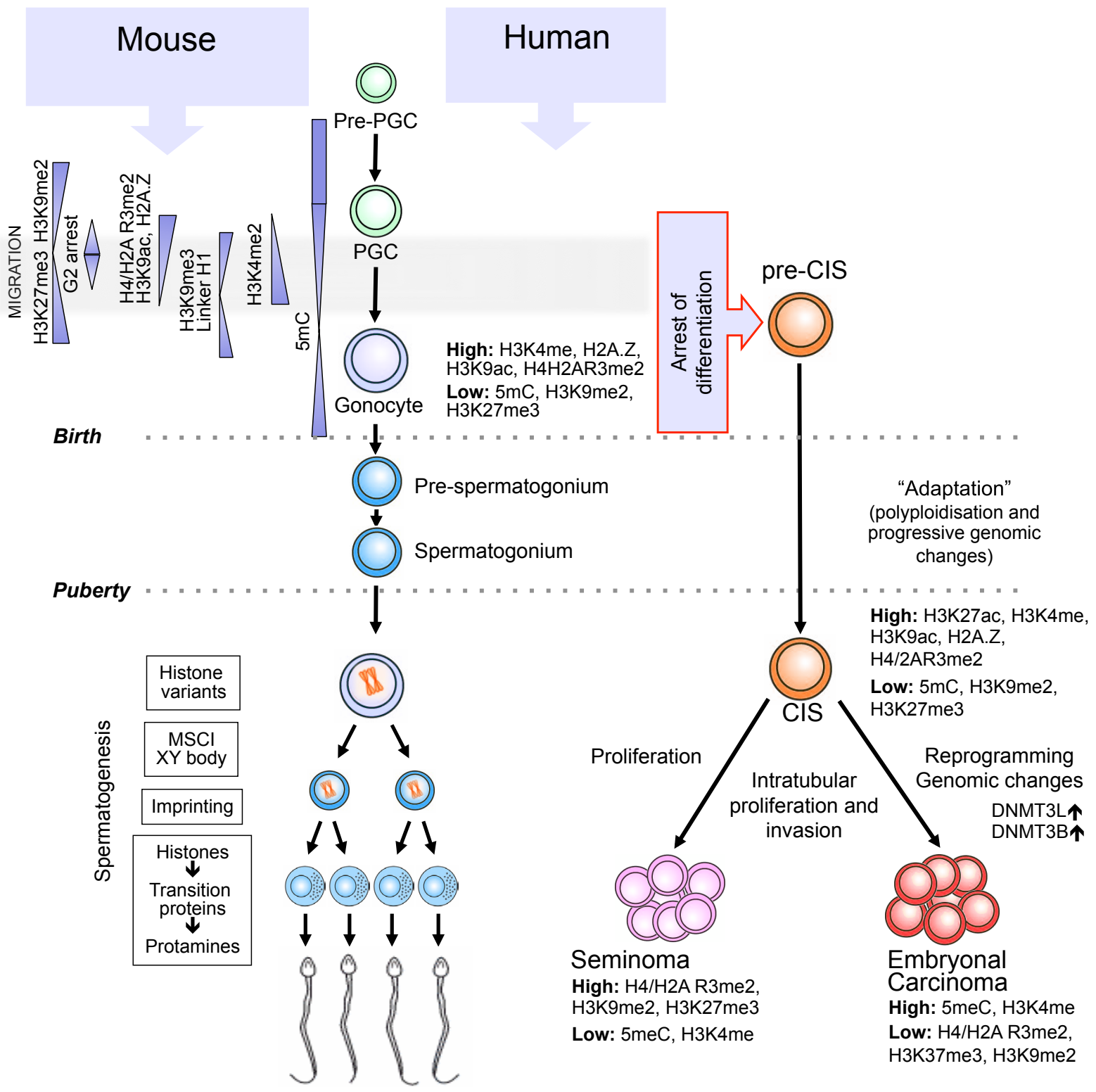

Fig. 2. Schematic drawing of germ cell development in human and mouse from specification of foetal primordial germ cells (PGCs) until pubertal onset of spermatogenesis and development of spermatozoa. After puberty only human germ cell development (left) is illustrated and neoplastic transformation of foetal germ cells into carcinoma in situ (CIS) is only observed in humans (right). In contrast to mice, very little is known about epigenetic patterns during human foetal germ cell development. DNA methylation patterns are greatly simplified as several waves of DNA demethylation occur and different categories of sequence (CpG, non-CpG, repeat elements, X chromosome, imprinted genes etc.) may be independently regulated. Accordingly, represented regulations are not exact but are intended as an overview. Data on H3K27me3 (Hajkova et al., 2008, Seki et al., 2007) is somewhat divergent and the depicted pattern is adapted from Seki et al., 2007. The only non-seminoma depicted is the embryonal carcinoma as this is the most investigated non-seminoma subtype. MSCl; Meiotic sex chromosome inactivation, CIS; carcinoma in situ, PGC; primordial germ cell. 
protooncogene c-kit protein were also found to be highly expressed in human foetal germ cells (Jørgensen et al., 1995). Subsequently several comparative studies of protein markers (reviewed in RajpertDe Meyts et al., 2003) and global gene expression profiles of CIS cells (Almstrup et al., 2004, Almstrup et al., 2007, Sonne et al., 2009a) further substantiated that CIS cells are indeed very similar to gonocytes. Moreover, we have recently shown that miRNA profile of CIS cells partially overlaps with that of foetal gonocytes (Novotny et al., 2012).

Our current hypothesis stipulates that foetal germ cells (gonocytes or PGCs) are arrested during perinatal development, probably due to an under-virilisation of the developing somatic niche, and hence give rise to dormant pre-CIS cells. Further transformation of pre-CIS cells, most likely occurs as a response to the changed endocrine environment during the peri- and post-pubertal testicular development and ultimately leads to malignant transformation and proliferation. As pre-CIS cells develop into "real" neoplastic CIS cells they undergo polyploidisation (Oosterhuis et al., 1989) and acquire a characteristic pattern of genomic aberrations, including gain of chromosome 12p (Ottesen et al., 2003, Rosenberg et al., 2000), often seen as the isochromosome 12p (Atkin and Baker, 1982). In analogy to PGCs and gonocytes, CIS cells express transcription factors associated with embryonic stem cell pluripotency, including e.g., POU5F1/OCT-3/4, NANOG, T1A-2, MYCL1, GDF3, LIN28-A, DPPA4, DPPA5, KIT and AP-2 $\gamma$ (Almstrup et al., 2004, Biermann et al., 2007, Gillis et al., 2011, Hoei-Hansen et al., 2005, Hoei-Hansen et al., 2004, Looijenga et al., 2003, Skotheim et al., 2005, Sperger et al., 2003).

In accordance with the expression pattern of genes and transcription factors associated with pluripotency and foetal expression patterns, the epigenetic pattern of CIS is associated with an open and permissive chromatin structure (Almstrup et al., 2010). CIS cells contain very low levels of DNA methylation when detected by immunohistochemical staining for 5-methyl-cytosine (Netto et al., 2008) as shown in Fig. 1B. Histone modifications H3K9me2 and $\mathrm{H} 3 \mathrm{~K} 27 \mathrm{me} 3$, both associated with a restrictive chromatin structure, were absent in CIS cells but H3K4me1 (Fig. 1D), H3K4me2/3, $\mathrm{H} 3 \mathrm{~K} 9 \mathrm{ac}$ (Fig. 1E) and the histone variant H2A.Z, which are all modifications associated with active and permissive chromatin structure, were abundantly present (Almstrup et al., 2010). This epigenetic pattern, in accordance to the epigenetics of mouse PGCs (see above), indicates that the CIS cells are arrested in the transition between H3K9me2 erasure (E7.5) and establishment of H3K27me3 (E8.25). However, in comparison to human foetal germ cells the CIS pattern reflects a much larger developmental time span, as human foetal gonocytes still show low levels of H3K9me2 and H327me3 in GW24 (Almstrup et al., 2010). The permissive and foetal-like epigenetic state of CIS will also dictate massive transcription, and we have shown that, unlike mouse PGCs, the CIS cells have an active RNA polymerase II and show a great proliferation rate (Almstrup et al., 2010). In accordance to this observation we showed that also H3K27ac is abundantly present in CIS cells (Fig. 1C). The H3K27ac mark has been found to co-localize to a proportion of H3K4me1-marked enhancer regions, but has also been found to separate active enhancers (H3K27ac+) from poised enhancers (H3K27ac-) and hence more truly reflects transcriptional activity. Active enhancers marked with both $\mathrm{H} 3 \mathrm{~K} 27 \mathrm{ac}$ and H3K4me1 were found to be associated with developmental genes typical of multipotent stem cells (Creyghton et al., 2010).
Interestingly both of these marks are abundant in CIS cells (Fig. 1C). In addition to the above-mentioned epigenetic marks in CIS cells, H3K9me3, HP1 $\alpha$ and $\gamma$ (Bartkova et al., 2011) as well as H4/H2AR3me2 (Eckert et al., 2008) have also been found at high levels in CIS cells.

The epigenetic patterns of normal foetal germ cell development and derivation of human foetal germ cells into neoplastic CIS cells are illustrated in Fig. 2.

\section{Epigenetic patterns in overt germ cell tumours}

The permissive and foetal-like epigenetic profile of CIS cells is lost once the CIS cells differentiate into an overt tumour. The overt tumour manifests either as a seminoma or non-seminoma, with very distinct histology as described above. It is yet elusive which mechanisms are responsible for the development of the two very different tumour types from the same cell of origin (CIS). Seminomas and non-seminomas have different epigenetic profiles and epigenetics may play an important role in their tumourigenesis. The epigenetic pattern of seminomas is characterized by high levels of H3K9me2, H3K27me3, H3K4me1 and H2A.Z, but erasure of H3K4me2/3 and H3K9ac compared to CIS. On the other hand, the undifferentiated component of non-seminomas, embryonal carcinoma (EC), displays high levels of DNA methylation, but shows similar levels of histone modifications to CIS cells (Netto et al., 2008, Smiraglia et al., 2002) (see Fig 2).

It is well recognized that DNA methylation plays a crucial role in tumourigenesis of somatic cancers. The genome of somatic cancer cells is characterized by global hypomethylation, which has been associated with genomic instability (Eden et al., 2003). In this way the hypomethylated genome of seminomas resembles that of somatic cancers, whereas the non-seminomatous germ cell tumour differs as it retains high levels of DNA methylation (Netto et al., 2008, Smiraglia et al., 2002). Furthermore, TGCTs has been found to differ from somatic cancers in the degree of hypomethylation of DNA repetitive elements, where hypomethylation of LINE1 and Alu repeats is more pronounced in seminomas compared to somatic cancers (Ushida et al., 2012). Non-seminomas show more pronounced hypomethylation of LINE1 as well, but are observed to be methylated atAlu repeats underlining the differential methylation pattern between the two types of TGCTs. Hypomethylated areas in the genome of the germline have in addition been ascribed to a much higher mutation rate than highly methylated areas ( $\mathrm{Li}$ et al., 2012).

In parallel to global hypomethylation, hypermethylation of gene promoters, resulting in silencing and inactivation of tumour suppressor genes (TSGs) is a hallmark of somatic cancers (reviewed in Herman, 1999). As in somatic cancers, TSGs are hypermethylated in both seminomas and non-seminomas (Brait et al., 2012); however distinct promoter methylation profiles between the two types of TGCTs exist, possibly explaining how the two tumour types are able to develop from the same cell of origin.

We have recently investigated the expression of a broad range of epigenetic marks in the rare spermatocytic seminoma (SS) that represents $1-2 \%$ of all seminomas (Kristensen et al., 2012). In contrast to the common TGCTs, SS occurs in elder men at 45-80 years of age and is usually benign. Most importantly SS originates from spermatogonia - and not from CIS, and not from foetal gonocytes. However, the epigenetic pattern of SS does not seem to match the 
pattern found in spermatogonia, e.g. a low level of DNAmethylation is found in SS, whereas spermatogonia are highly methylated. In general, a very heterogeneous epigenetic pattern is observed in SS, in contrast to the more uniform pattern observed in seminoma and non-seminoma. The histone modifications H2A.Z and H3K9me2 are the most consistently expressed epigenetic marks, whereas H3K4me1, H3K4me2/3, H3K9ac and H3K27me3 are expressed at various levels within the same tumour. SS thereby displays a markedly heterogeneous epigenetic landscape, implying that each cell comprising the tumour might be able to individually modify its epigenetic state. We have suggested that this phenomenon may be a consequence of the loss of contact to the somatic niche, which under normal circumstances regulates the maturation of the surrounding germ cells including their epigenetic state.

\section{Concluding remarks}

Testicular cancer originates from foetal germ cells at the time where massive epigenetic reprogramming is taking place. Epigenetic reprogramming is a pre-requisite of proper germ cell development and it is hence likely that alterations in the epigenetic modifications may cause testicular cancer. The epigenetic reprogramming is vulnerable to external environmental stimuli and this is consistent with environmental factors being predominantly responsible in aetiology of testicular cancer. However only scarce information exists on human epigenetic cues in foetal germ cells and further studies are needed to deduce which epigenetic modifications may be affected and in which part of the genome.

\section{Acknowledgements}

This work was supported by the Lundbeck Foundation and the Danish Cancer Society.

\section{References}

AKHTAR, M. and SIDIKI, Y. (1979). Undifferentiated intratubular germ cell tumor of the testis: light and electron microscopic study of a unique case. Cancer43:2332-2339.

ALBRECHTSEN, R., NIELSEN, M., SKAKKEBAEK, N. and WEWER, U. (1982). Carcinoma in situ of the testis. Some ultrastructural characteristics of germ cells. Acta Pathol Microbiol Immunol Scand A 90: 301-303.

ALMSTRUP, K., HOEI-HANSEN, C., WIRKNER, U., BLAKE, J., SCHWAGER, C., ANSORGE, W., NIELSEN, J., SKAKKEBAEK, N., RAJPERT-DE MEYTS, E. and LEFFERS, H. (2004). Embryonic stem cell-like features of testicular carcinoma in situ revealed by genome-wide gene expression profiling. Cancer Res 64: 4736-4743.

ALMSTRUP, K., LEFFERS, H., LOTHE, R., SKAKKEBAEK, N., SONNE, S., NIELSEN, J., RAJPERT-DE MEYTS, E. and SKOTHEIM, R. (2007). Improved gene expression signature of testicular carcinoma in situ. Int J Andro/30: 292-302; discussion 303.

ALMSTRUP, K., NIELSEN, J.E., MLYNARSKA, O., JANSEN, M.T., JORGENSEN, A., SKAKKEBAEK, N.E. and RAJPERT-DE MEYTS, E. (2010). Carcinoma in situ testis displays permissive chromatin modifications similar to immature foetal germ cells. Brit. J. Cancer 103: 1269-1276.

ANCELIN, K., LANGE, U., HAJKOVA, P., SCHNEIDER, R., BANNISTER, A., KOUZARIDES, T. and SURANI, M. (2006). Blimp1 associates with Prmt5 and directs histone arginine methylation in mouse germ cells. Nat Cell Biol 8: 623-630.

ATKIN, N. and BAKER, M. (1982). Specific chromosome change, i(12p), in testicular tumours? Lancet 2: 1349 .

BARTKOVA, J., MOUDRY, P., HODNY, Z., LUKAS, J., RAJPERT-DE MEYTS, E. and BARTEK, J. (2011). Heterochromatin marks HP1gamma, HP1alpha and H3K9me3, and DNA damage response activation in human testis development and germ cell tumours. Int J Androl 34: e103-113.

BERNARDINO, J., LOMBARD, M., NIVELEAU, A. and DUTRILLAUX, B. (2000). Common methylation characteristics of sex chromosomes in somatic and germ cells from mouse, lemur and human. Chromosome Res 8: 513-525.

BERTHELSEN, J.G., SKAKKEBAEK, N.E., MOGENSEN, P. and SØRENSEN, B.L. (1979). Incidence of carcinoma in situ of germ cells in contralateral testis of men with testicular tumours. Br Med J 2: 363-364.

BIERMANN, K., HEUKAMP, L., STEGER, K., ZHOU, H., FRANKE, F., GUETGEMANN, I., SONNACK, V., BREHM, R., BERG, J., BASTIAN, P. et al., (2007). Gene expression profiling identifies new biological markers of neoplastic germ cells. Anticancer Res 27: 3091-3100.

BOSTICK, M., KIM, J.K., ESTEVE, P.O., CLARK, A., PRADHAN, S. and JACOBSEN, S.E. (2007). UHRF1 plays a role in maintaining DNA methylation in mammalian cells. Science 317: 1760-1764.

BRAIT, M., MALDONADO, L., BEGUM, S., LOYO, M., WEHLE, D., TAVORA, F.F., LOOIJENGA, L.H., KOWALSKI, J., ZHANG, Z., ROSENBAUM, E. et al., (2012). DNA methylation profiles delineate epigenetic heterogeneity in seminoma and non-seminoma. Br J Cancer 106: 414-423.

CHIA, V., QURAISHI, S., DEVESA, S., PURDUE, M., COOK, M. and MCGLYNN, K. (2010). International trends in the incidence of testicular cancer, 1973-2002. Cancer Epidemiol Biomarkers Prev 19: 1151-1159.

CREYGHTON, M.P., CHENG, A.W., WELSTEAD, G.G., KOOISTRA, T., CAREY, B.W., STEINE, E.J., HANNA, J., LODATO, M.A., FRAMPTON, G.M., SHARP, P.A. et al., (2010). Histone H3K27ac separates active from poised enhancers and predicts developmental state. Proc Natl Acad Sci USA 107: 21931-21936.

DEL MAZO, J., PRANTERA, G., TORRES, M. and FERRARO, M. (1994). DNA methylation changes during mouse spermatogenesis. Chromosome Res 2: 147-152.

DIECKMANN, K. and PICHLMEIER, U. (2004). Clinical epidemiology of testicular germ cell tumors. World J Urol 22: 2-14.

DOEGE, C.A., INOUE, K., YAMASHITA, T., RHEE, D.B., TRAVIS, S., FUJITA, R., GUARNIERI, P., BHAGAT, G., VANTI, W.B., SHIH, A. et al., (2012). Early-stage epigenetic modification during somatic cell reprogramming by Parp1 and Tet2. Nature 488:652655.

ECKERT, D., BIERMANN, K., NETTERSHEIM, D., GILLIS, A., STEGER, K., JÄCK, H., MÜLLER, A., LOOIJENGA, L. and SCHORLE, H. (2008). Expression of BLIMP1/ PRMT5 and concurrent histone $\mathrm{H} 2 \mathrm{~A} / \mathrm{H} 4$ arginine 3 dimethylation in fetal germ cells, CIS/IGCNU and germ cell tumors. BMC Dev Biol 8: 106.

EDEN, A., GAUDET, F., WAGHMARE, A. and JAENISCH, R. (2003). Chromosomal instability and tumors promoted by DNA hypomethylation. Science 300: 455.

FEIL, R. and FRAGA, M.F. (2011). Epigenetics and the environment: emerging patterns and implications. Nat Rev Genet 13: 97-109.

FISHER, J., MACPHERSON, S., MARCHETTI, N. and SHARPE, R. (2003). Human 'testicular dysgenesis syndrome': a possible model using in-utero exposure of the rat to dibutyl phthalate. Hum Reprod 18: 1383-1394.

FOSTER, P., MYLCHREEST, E., GAIDO, K. and SAR, M. (2001). Effects of phthalate esters on the developing reproductive tract of male rats. Hum Reprod Update 7: 231-235.

FUJIMOTO, T., MIYAYAMA, Y. and FUYUTA, M. (1977). The origin, migration and fine morphology of human primordial germ cells. Anat Rec 188: 315-330.

GILLIS, A.J., STOOP, H., BIERMANN, K., VAN GURP, R.J., SWARTZMAN, E., CRIBBES, S., FERLINZ, A., SHANNON, M., OOSTERHUIS, J.W. and LOOIJENGA, L.H. (2011). Expression and interdependencies of pluripotency factors LIN28, OCT3/4, NANOG and SOX2 in human testicular germ cells and tumours of the testis. Int $J$ Androl 34: e160-e174.

GUIBERT, S., FORNE, T. and WEBER, M. (2012). Global profiling of DNA methylation erasure in mouse primordial germ cells. Genome Res 22: 633-641.

HAJKOVA, P., ANCELIN, K., WALDMANN, T., LACOSTE, N., LANGE, U., CESARI, F., LEE, C., ALMOUZNI, G., SCHNEIDER, R. and SURANI, M. (2008). Chromatin dynamics during epigenetic reprogramming in the mouse germ line. Nature 452: 877-881.

HAJKOVA, P., ERHARDT, S., LANE, N., HAAF, T., EL-MAARRI, O., REIK, W., WALTER, J. and SURANI, M. (2002). Epigenetic reprogramming in mouse primordial germ cells. Mech Dev 117: 15-23.

HAJKOVA, P., JEFFRIES, S.J., LEE, C., MILLER, N., JACKSON, S.P. and SURANI, M.A. (2010). Genome-wide reprogramming in the mouse germ line entails the base excision repair pathway. Science 329: 78-82.

HARDELL, L., VAN BAVEL, B., LINDSTRÖM, G., CARLBERG, M., DREIFALDT, A., WIJKSTRÖM, H., STARKHAMMAR, H., ERIKSSON, M., HALLQUIST, A. and 
KOLMERT, T. (2003). Increased concentrations of polychlorinated biphenyls, hexachlorobenzene, and chlordanes in mothers of men with testicular cancer. Environ Health Perspect 111: 930-934.

HEMMINKI, K. and LI, X. (2002a). Cancer risks in childhood and adolescence among the offspring of immigrants to Sweden. Br J Cancer 86: 1414-1418.

HEMMINKI, K. and LI, X. (2002b). Cancer risks in second-generation immigrants to Sweden. Int J Cancer 99: 229-237.

HEMMINKI, K., LI, X. and CZENE, K. (2002). Cancer risks in first-generation immigrants to Sweden. Int J Cancer 99: 218-228.

HERMAN, J.G. (1999). Hypermethylation of tumor suppressor genes in cancer. Semin Cancer Biol 9: 359-367.

HIGUCHI, T., PALMER, J., GRAY, L.J. and VEERAMACHANENI, D. (2003). Effects of dibutyl phthalate in male rabbits following in utero, adolescent, or postpubertal exposure. Toxicol Sci 72: 301-313.

HOEI-HANSEN, C., ALMSTRUP, K., NIELSEN, J., BRASK SONNE, S., GRAEM, N., SKAKKEBAEK, N., LEFFERS, $H$. and RAJPERT-DE MEYTS, E. (2005). Stem cell pluripotency factor NANOG is expressed in human fetal gonocytes, testicular carcinoma in situ and germ cell tumours. Histopathology 47: 48-56.

HOEI-HANSEN, C.E., HOLM, M., RAJPERT-DE MEYTS, E. and SKAKKEBAEK, N.E. (2003). Histological evidence of testicular dysgenesis in contralateral biopsies from 218 patients with testicular germ cell cancer. J. Pathology 200: 370-374.

HOEI-HANSEN, C.E., NIELSEN, J.E., ALMSTRUP, K., SONNE, S.B., GRAEM, N., SKAKKEBAEK, N.E., LEFFERS, H. and RAJPERT-DE MEYTS, E. (2004). Transcription factor AP-2gamma is a developmentally regulated marker of testicular carcinoma in situ and germ cell tumors. Clin Cancer Res 10: 8521-8530.

HUYGHE, E., MATSUDA, T. and THONNEAU, P. (2003). Increasing incidence of testicular cancer worldwide: a review. J Urol 170: 5-11.

HYLDIG, S.M., CROXALL, N., CONTRERAS, D.A., THOMSEN, P.D. and ALBERIO, R. (2011a). Epigenetic reprogramming in the porcine germ line. BMC Dev Biol11: 11.

HYLDIG, S.M., OSTRUP, O., VEJLSTED, M. and THOMSEN, P.D. (2011b). Changes of DNA methylation level and spatial arrangement of primordial germ cells in embryonic day 15 to embryonic day 28 pig embryos. Biol Reprod 84: 1087-1093.

JORGENSEN, A., NIELSEN, J.E., BLOMBERG JENSEN, M., GRAEM, N. and RAJPERT-DE MEYTS, E. (2012). Analysis of meiosis regulators in human gonads: a sexually dimorphic spatio-temporal expression pattern suggests involvement of DMRT1 in meiotic entry. Mol Hum Reprod.

JØRGENSEN, N., RAJPERT-DE MEYTS, E., GRAEM, N., MÜLLER, J., GIWERCMAN, A. and SKAKKEBAEK, N. (1995). Expression of immunohistochemical markers for testicular carcinoma in situ by normal human fetal germ cells. Lab Invest 72: 223-231.

KOOPMAN, P. (2010). The delicate balance between male and female sex determining pathways: potential for disruption of early steps in sexual development. Int J Androl 33: 252-258

KRENTZ, A.D., MURPHY, M.W., SARVER, A.L., GRISWOLD, M.D., BARDWELL, V.J. and ZARKOWER, D. (2011). DMRT1 promotes oogenesis by transcriptional activation of Stra8 in the mammalian fetal ovary. Dev Biol 356: 63-70.

KRISTENSEN, D.G., MLYNARSKA, O., NIELSEN, J.E., JACOBSEN, G.K., RAJPERTDE MEYTS, E. and ALMSTRUP, K. (2012). Heterogeneity of chromatin modifications in testicular spermatocytic seminoma point toward an epigenetically unstable phenotype. Cancer Genet 205: 425-431.

LI, J., HARRIS, R.A., CHEUNG, S.W., COARFA, C., JEONG, M., GOODELL, M.A., WHITE, L.D., PATEL, A., KANG, S.H., SHAW, C. et al., (2012). Genomic hypomethylation in the human germline associates with selective structural mutability in the human genome. PLoS Genet 8: e1002692.

LI, J., LEES-MURDOCK, D., XU, G. and WALSH, C. (2004). Timing of establishment of paternal methylation imprints in the mouse. Genomics 84: 952-960.

LOOIJENGA, L., STOOP, H., DE LEEUW, H., DE GOUVEIABRAZAO, C., GILLIS, A., VAN ROOZENDAAL, K., VAN ZOELEN, E., WEBER, R., WOLFFENBUTTEL, K. VAN DEKKEN, H. et al., (2003). POU5F1 (OCT3/4) identifies cells with pluripotent potential in human germ cell tumors. Cancer Res 63: 2244-2250.

MAHOOD, I., HALLMARK, N., MCKINNELL, C., WALKER, M., FISHER, J. and SHARPE, R. (2005). Abnormal Leydig Cell aggregation in the fetal testis of rats exposed to di (n-butyl) phthalate and its possible role in testicular dysgenesis. Endocrinology 146: 613-623.

MANCINI, M., CARMIGNANI, L., GAZZANO, G., SAGONE, P., GADDA, F., BOSARI, S., ROCCO, F. and COLPI, G. (2007). High prevalence of testicular cancer in azoospermic men without spermatogenesis. Hum Reprod 22: 1042-1046.

MATSON, C.K., MURPHY, M.W., GRISWOLD, M.D., YOSHIDA, S., BARDWELL, V.J. and ZARKOWER, D. (2010). The mammalian doublesex homolog DMRT1 is a transcriptional gatekeeper that controls the mitosis versus meiosis decision in male germ cells. Dev Cell 19: 612-624.

MOUL, J., SCHANNE, F., THOMPSON, I., FRAZIER, H., PERETSMAN, S., WETTLAUFER, J., ROZANSKI, T., STACK, R., KREDER, K. and HOFFMAN, K. (1994). Testicular cancer in blacks. A multicenter experience. Cancer73:388-393.

NETTO, G., NAKAI, Y., NAKAYAMA, M., JADALLAH, S., TOUBAJI, A., NONOMURA, N. ALBADINE, R., HICKS, J., EPSTEIN, J., YEGNASUBRAMANIAN, S. et al., (2008). Global DNA hypomethylation in intratubular germ cell neoplasia and seminoma, but not in nonseminomatous male germ cell tumors. Mod Pathol 21: 1337-1344.

NIELSEN, H., NIELSEN, M. and SKAKKEBAEK, N. (1974). The fine structure of possible carcinoma-in-situ in the seminiferous tubules in the testis of four infertile men. Acta Pathol Microbiol Scand A 82: 235-248.

NORRIS, D., PATEL, D., KAY, G., PENNY, G., BROCKDORFF, N., SHEARDOWN, S. and RASTAN, S. (1994). Evidence that random and imprinted Xist expression is controlled by preemptive methylation. Cell $77: 41-51$.

NOVOTNY, G.W., BELLING, K., BRAMSEN, J.B., NIELSEN, J.E., BORK-JENSEN J., ALMSTRUP, K., SONNE, S.B., KJEMS, J., RAJPERT-DE MEYTS, E. and LEFFERS, H. (2012). MicroRNA expression profiling of carcinoma in situ (CIS) cells of the testis. Endocr Relat Cancer 19: 365-379.

OHINATA, Y., PAYER, B., O'CARROLL, D., ANCELIN, K., ONO, Y., SANO, M. BARTON, S., OBUKHANYCH, T., NUSSENZWEIG, M., TARAKHOVSKY, A et al., (2005). Blimp1 is a critical determinant of the germ cell lineage in mice. Nature 436: 207-213.

OOSTERHUIS, J., CASTEDO, S., DE JONG, B., CORNELISSE, C., DAM, A., SLEIJFER, D. and SCHRAFFORDT KOOPS, H. (1989). Ploidy of primary germ cell tumors of the testis. Pathogenetic and clinical relevance. Lab Invest 60: 14-21.

OTTESEN, A., SKAKKEBAEK, N., LUNDSTEEN, C., LEFFERS, H., LARSEN, J. and RAJPERT-DE MEYTS, E. (2003). High-resolution comparative genomic hybridization detects extra chromosome arm 12p material in most cases of carcinoma in situ adjacent to overt germ cell tumors, but not before the invasive tumor development. Genes Chromosomes Cancer 38: 117-125.

PERRETT, R., TURNPENNY, L., ECKERT, J., O'SHEA, M., SONNE, S., CAMERON I., WILSON, D., MEYTS, E. and HANLEY, N. (2008). The early human germ cell lineage does not express SOX2 during in vivo development or upon in vitro culture. Biol Reprod 78: 852-858

POPP, C., DEAN, W., FENG, S., COKUS, S.J., ANDREWS, S., PELLEGRINI, M., JACOBSEN, S.E. and REIK, W. (2010). Genome-wide erasure of DNAmethylation in mouse primordial germ cells is affected by AID deficiency. Nature 463: 1101-1105.

RAJPERT-DE MEYTS, E. (2006). Developmental model for the pathogenesis of testicular carcinoma in situ: genetic and environmental aspects. Human Reproduction Update 12: 303-323.

RAJPERT-DE MEYTS, E., BARTKOVA, J., SAMSON, M., HOEI-HANSEN, C. FRYDELUND-LARSEN, L., BARTEK, J. and SKAKKEBAEK, N. (2003). The emerging phenotype of the testicular carcinoma in situ germ cell. APMIS 111: 267-78; discussion 278-279.

REIK, W. and WALTER, J. (2001). Genomic imprinting: parental influence on the genome. Nat Rev Genet 2: 21-32.

ROSENBERG, C., VAN GURP, R., GEELEN, E., OOSTERHUIS, J. and LOOIJENGA L. (2000). Overrepresentation of the short arm of chromosome 12 is related to invasive growth of human testicular seminomas and nonseminomas. Oncogene 19: 5858-5862.

SEKI, Y., HAYASHI, K., ITOH, K., MIZUGAKI, M., SAITOU, M. and MATSUI, Y. (2005) Extensive and orderly reprogramming of genome-wide chromatin modifications associated with specification and early development of germ cells in mice. Dev Biol 278: 440-458.

SEKI, Y., YAMAJI, M., YABUTA, Y., SANO, M., SHIGETA, M., MATSUI, Y., SAGA, Y., TACHIBANA, M., SHINKAI, Y. and SAITOU, M. (2007). Cellular dynamics associated with the genome-wide epigenetic reprogramming in migrating primordial germ cells in mice. Development 134: 2627-2638.

SKAKKEBAEK, N. (1972). Possible carcinoma-in-situ of the testis. Lancet2: 516-517.

SKAKKEBAEK, N., BERTHELSEN, J., GIWERCMAN, A. and MÜLLER, J. (1987). Carcinoma-in-situ of the testis: possible origin from gonocytes and precursor of all types of germ cell tumours except spermatocytoma. Int J Androl 10: 19-28. 
SKAKKEBAEK, N.E., HOLM, M., HOEI-HANSEN, C., JORGENSEN, N. and RAJPERTDE MEYTS, E. (2003). Association between testicular dysgenesis syndrome (TDS) and testicular neoplasia: Evidence from 20 adult patients with signs of maldevelopment of the testis. APMIS 111: 1-11.

SKAKKEBAEK, N.E., RAJPERT-DE MEYTS, E. and MAIN, K.M. (2001). Testicular dysgenesis syndrome: an increasingly common developmental disorder with environmental aspects. Hum Reprod 16: 972-978.

SKOTHEIM, R., LIND, G., MONNI, O., NESLAND, J., ABELER, V., FOSSÅ, S., DUALE, N., BRUNBORG, G., KALLIONIEMI, O., ANDREWS, P. et al., (2005). Differentiation of human embryonal carcinomas in vitro and in vivo reveals expression profiles relevant to normal development. Cancer Res 65: 5588-5598.

SMIRAGLIA, D., SZYMANSKA, J., KRAGGERUD, S., LOTHE, R., PELTOMÄKI, P. and PLASS, C. (2002). Distinct epigenetic phenotypes in seminomatous and nonseminomatous testicular germ cell tumors. Oncogene 21: 3909-3916.

SONNE, S., ALMSTRUP, K., DALGAARD, M., JUNCKER, A., EDSGARD, D., RUBAN, L., HARRISON, N., SCHWAGER, C., ABDOLLAHI, A., HUBER, P. et al., (2009a). Analysis of Gene Expression Profiles of Microdissected Cell Populations Indicates that Testicular Carcinoma In situ Is an Arrested Gonocyte. Cancer Res 69: 5241-5250.

SONNE, S.B., ALMSTRUP, K., DALGAARD, M., JUNCKER, A.S., EDSGARD, D., RUBAN, L., HARRISON, N.J., SCHWAGER, C., ABDOLLAHI, A., HUBER, P.E. et al., (2009b). Analysis of gene expression profiles of microdissected cell populations indicates that testicular carcinoma in situ is an arrested gonocyte. Cancer Res 69: 5241-5250.

SPERGER, J., CHEN, X., DRAPER, J., ANTOSIEWICZ, J., CHON, C., JONES, S., BROOKS, J., ANDREWS, P., BROWN, P. and THOMSON, J. (2003). Gene expression patterns in human embryonic stem cells and human pluripotent germ cell tumors. Proc Natl Acad Sci USA 100: 13350-13355.

TACHIBANA, M., MATSUMURA, Y., FUKUDA, M., KIMURA, H. and SHINKAI, Y. (2008). G9a/GLP complexes independently mediate H3K9 and DNA methylation to silence transcription. EMBO J 27: 2681-2690.
ULBRIGHT, T., AMIN, M. and YOUNG, R. (1999). Atlas of tumor pathology. Tumors of the testis, adnexa, spermatic cord, and scrotum. Armed Forces, Institute of Pathology, Washington DC.

USHIDA, H., KAWAKAMI, T., MINAMI, K., CHANO, T., OKABE, H., OKADA, Y. and OKAMOTO, K. (2012). Methylation profile of DNA repetitive elements in human testicular germ cell tumor. Mol Carcinog 51: 711-722.

WALSH, T., CROUGHAN, M., SCHEMBRI, M., CHAN, J. and TUREK, P. (2009) Increased risk of testicular germ cell cancer among infertile men. Arch Intern Med 169: 351-356.

WERMANN, H., STOOP, H., GILLIS, A.J., HONECKER, F., VAN GURP, R.J., AMMERPOHL, O., RICHTER, J., OOSTERHUIS, J.W., BOKEMEYER, C. and LOOIJENGA, L.H. (2010). Global DNA methylation in fetal human germ cells and germ cell tumours: association with differentiation and cisplatin resistance. J Pathol 221: 433-442.

WOOD, H. and ELDER, J. (2009). Cryptorchidism and testicular cancer: separating fact from fiction. J Urol 181: 452-461

XIE, W., HAN, S., KHAN, M. and DEJONG, J. (2002). Regulation of ALF gene expression in somatic and male germ line tissues involves partial and site-specific patterns of methylation. J Biol Chem 277: 17765-17774.

YABUTA, Y., KURIMOTO, K., OHINATA, Y., SEKI, Y. and SAITOU, M. (2006). Gene expression dynamics during germline specification in mice identified by quantitative single-cell gene expression profiling. Biol Reprod 75: 705-716.

ZAMPIERI, M., GUASTAFIERRO, T., CALABRESE, R., CICCARONE, F., BACALINI, M.G., REALE, A., PERILLI, M., PASSANANTI, C. and CAIAFA, P. (2012). ADP ribose polymers localized on Ctcf-Parp1-Dnmt1 complex prevent methylation of Ctcf target sites. Biochem J 441: 645-652.

ZAMPIERI, M., PASSANANTI, C., CALABRESE, R., PERILLI, M., CORBI, N., DE CAVE, F., GUASTAFIERRO, T., BACALINI, M.G., REALE, A., AMICOSANTE, G. et al., (2009). Parp1 localizes within the Dnmt1 promoter and protects its unmethylated state by its enzymatic activity. PLoS One 4: e4717. 


\section{Further Related Reading, published previously in the Int. J. Dev. Biol.}

Rediscovering pluripotency: from teratocarcinomas to embryonic stem cells Ivana Barbaric and Neil J. Harrison

Int. J. Dev. Biol. (2012) 56: 197-206

Foetal germ cells: striking the balance between pluripotency and differentiation Patrick Western

Int. J. Dev. Biol. (2009) 53: 393-409

Developmental fates of the mouse germ cell line Y Matsui

Int. J. Dev. Biol. (1998) 42: 1037-1042

A systematic molecular genetic approach to study mammalian germline development K Abe, M S Ko and G R MacGregor

Int. J. Dev. Biol. (1998) 42: 1051-1065

Teratocarcinoma: neoplastic lessons about normal embryogenesis

I Damjanov

Int. J. Dev. Biol. (1993) 37: 39-46

5 yr ISI Impact Factor $(2011)=2.959$
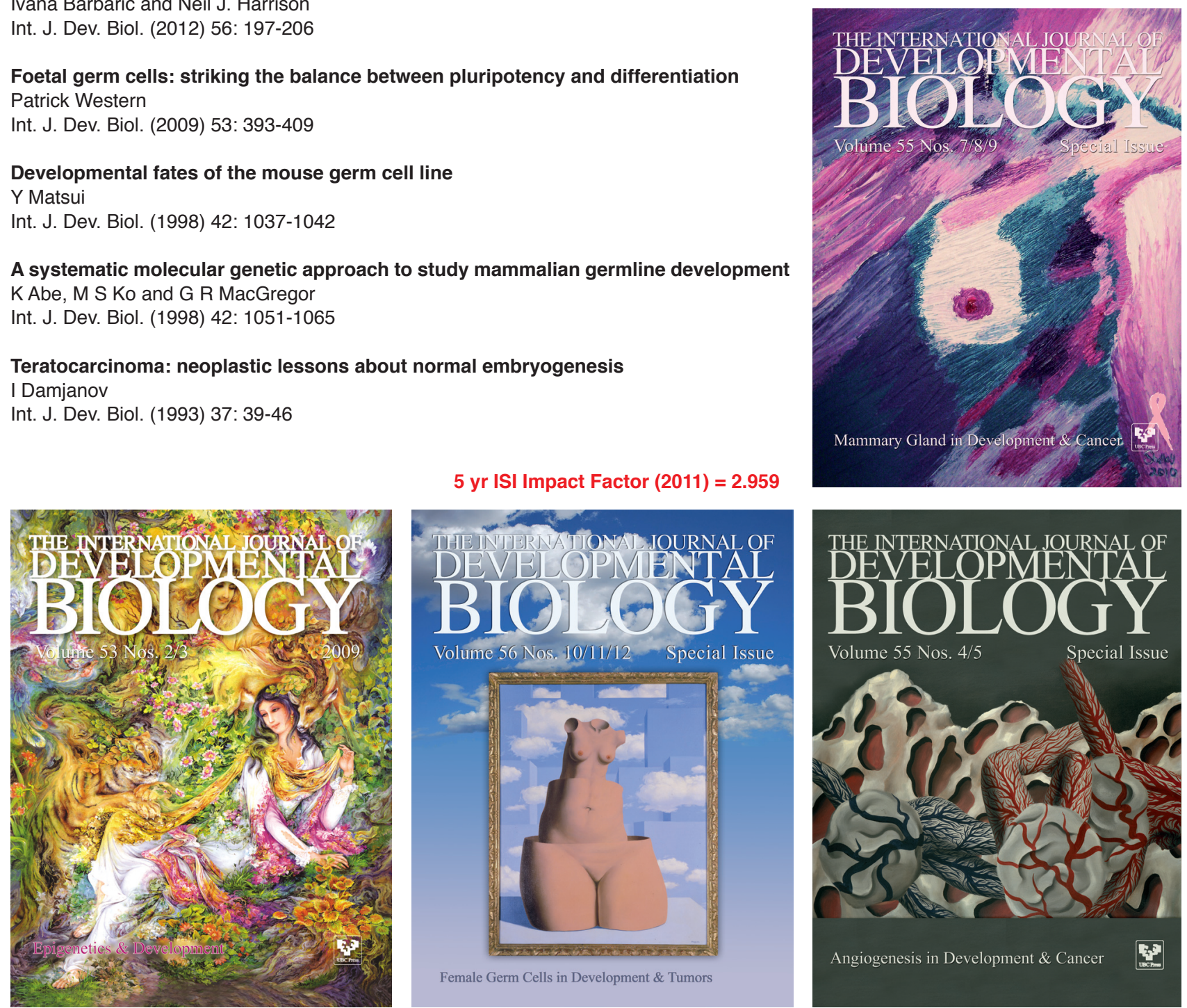